BENHA VETERINARY MEDICAL JOURNAL, VOL. 33, No. 2:193-199, DECEMBER, 2017

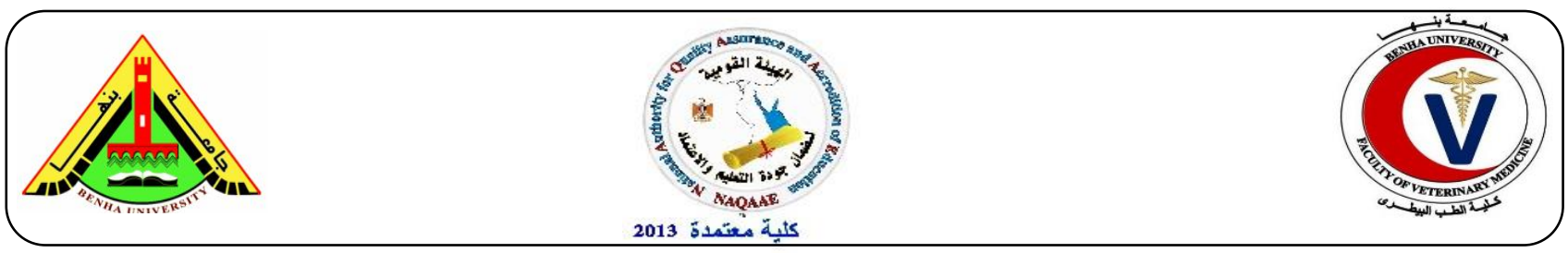

\title{
Keeping quality of inactivated respiratory virus vaccines (Pneumo-5)
}

\author{
Maha, R. Abd El-Fadil, Rasha,I. El Hawary and Fatma Fadel Warda \\ Veterinary Serum and Vaccine Research Institute, Abbassia, Cairo, Egypt
}

\begin{abstract}
In the keeping quality and the Efficacy of freshly locally prepared Bovine Respiratory virus vaccines (Pneumo-5) adjuvanted with either Aluminum Hydroxyl gel or montanoid oil , the serum neutralization test was used for humoral immunity evaluation using( potency sample value) as a parameter by studying the effect of different storage temperature on change on this value and its validity. it was found that the Gel adjuvanted pneumo-5 vaccine was valid for ( 15 month, 2 week and 1 week) in storage temperature $4-8^{\circ} \mathrm{C}($ refrigerator), $18-25^{\circ} \mathrm{C}$ ( room temperature) and $37^{\circ} \mathrm{C}$ (incubator) respectively but we found that the Oil adjuvanted pneumo-5 vaccine was valid for ( 24 month, 3 week and 2 week) in storage temperature $4-8^{\circ} \mathrm{C}$ (refrigerator), $18-25^{\circ} \mathrm{C}$ (room temperature) and $37^{\circ} \mathrm{C}$ (incubator) respectively after that the vaccine becomes invalid .
\end{abstract}

(http://www.bvmj.bu.edu.eg)

(BVMJ-33(2): 193-199, DECEMBER, 2017)

\section{INTRODUCTION}

Bovine respiratory diseases (BRD) have an impact issue on the beef and dairy cattle industry, both for stocker and feedlot entities. Economic losses result from death, decreased performance of diseased cattle, lowered weight gain, increased cost of gain, reduced carcass value and treatment costs (Fulton et al., 2002). Pneumoenteritis problem in cattle and calves in Egypt is caused by viral agents include Bovine Viral Diarrhea virus (BVDV) with its two genotype ; genotype-1 and genotype-2 (Abdel-Fadil, 2007), Infectious Bovine Rhinotracheitis Virus (IBRV), Parainfluenza-3 Virus (PI-3V) and Bovine Respiratory Syncytial Virus (BRSV) (Samira et al., 2001). Prevention and control of BRD is much more successful and economically feasible than treatment. An ideal processing protocol should include vaccination of the herd with safe, potent and effective gel and oily adjuvanted inactivated Pneumo-5 vaccines to develop an adequate immune response contain the previous five viruses protection coat (Rasha et al., 2016). Locally prepared inactivated gel pneumo-3 vaccine containing three viruses (BVDV-1, IBRV and PI-3V) was first edition of locally prepared vaccine produce to face that syndrome in Egypt then Pneummo-4 vaccine was produced by adding(BRSV) to pneumo-3 composition .pneumo-5 developed by adding (BVDV-2) (Abdel-Fadil 2012).

The aim of this work was the studding of Keeping quality of pneumo-5 vaccines from Physical factor as Thermo stability of pneumo-5 vaccine at $\left(4-8^{\circ} \mathrm{C}\right.$ in refrigerator), ( $18-22^{\circ} \mathrm{C}$ in room temperature) and at $\left(37^{\circ} \mathrm{C}\right.$ in incubator) . 


\section{MATERIALS AND METHODS}

1. pneumo-5 Viruses in the prepared vaccines:

1.1. Bovine viral diarrhea virus genotype-1 (BVD-1)

A local Egyptian strain (Iman strain) with a titer of $10^{6.5} \mathrm{TCID}_{50} / \mathrm{ml}$.).

1.2. Bovine viral diarrhea virus genotype2(BVD-2)

A cytopathic (strain 125) with a titer of $10^{6.5}$ $\mathrm{TCID}_{50} / \mathrm{ml}$.

Infectious Bovine Rhinotracheitis virus (IBRV): A local isolate of "Abou Hammad strain" with a titer of $10^{7.5} \mathrm{TCID}_{50} / \mathrm{ml}$.

1.3. Parainfluenza-3 virus (PI-3V)

Egyptian strain of PI-3 (Strain 45) with a titer of $10^{8} \mathrm{TCID}_{50} / \mathrm{ml}$.

\subsection{Bovine respiratory syncytial virus}

These viruses were supplied by Rinderpest Like Diseases Research Department, Veterinary Serum and Vaccine Research Institute Abbasia, Cairo (VSVRI) and used in vaccine preparation and SNT. And all viruses propagated on MDBK cell culture.

\section{Inactivation}

Bromo-ethyleneimine hydrobromide (BEI) was used for inactivation of the vaccinal viruses and. Sodium thiosulphate was used to stop the action of BEI according to Bahnemann (1975).

\section{Montanide Oil ISA 206}

It is a mineral oil based adjuvant a double emulsion . It was obtained from Seppic, Paris, France (2002)

\section{Aluminium hydroxide gel:}

It was used as stabilizer and adjuvant on the vaccine preparation. It was sterilized by autoclaving for 20 minutes at $121^{\circ} \mathrm{C}$ and $\mathrm{pH}$ was adjusted to 6.6 according to( Lei, 1985).

\section{Animals}

\subsection{White Swiss mice}

20 Albino Swiss weaned mice of 1821days of age were used for safety test of the prepared vaccine. They were obtained from Laboratory Animals Department, Veterinary Serum and Vaccine Research Institute, Abbasia, Cairo.

5.2. Calves
A total of 64 susceptible healthy male native breed calves aged about 6 months were used to study the safety and potency of the prepared vaccine. These animals were found to be free from antibodies against the used viruses using SNT.

\section{Vaccine preparation}

The used viruses were propagated in MDBK cell line and the virus suspensions were harvested then subjected to two cycles of freezing and thawing and inactivated by $0.01 \mathrm{M}$ of binary ethylenimine according to Zeidan et al. (1999). Sodium thiosulphate $2 \%$ of $20 \%$ was added to stop the action of BEI then divided into 2 part for preparation of the two different type of pneumo-5 vaccine.

\section{1 preparation of oil adjuvanted pneumo-5} vaccine:

Equal volumes of the inactivated virus fluid was mixed together and thoroughly mixed with montanide oil ISA 206 at a ratio 1:1 (vol/vol) according to (Barteling et al., 1990). The PH was adjusted to 7.5.

6.1 preparation of Gel adjuvanted pneumo-5 vaccine:

Mix the other part of viral suspension with aluminium hydroxide gel $(25 \%)$ and using of thiomersal $0.001 \%$ as a preservative according to Samira et al. (2001). Thiomersal was added as a vaccine preservative at final concentration of $0.001 \%$ to the both type of prepared vaccines and distributed in sterile bottles of $50 \mathrm{ml}$

7. Quality control of the prepared vaccine.

7.1. Sterility test

It was performed in according to (Maha, 2012)

\subsection{Safety tests}

In mice and In calves was adopted according to ( maha , 2012)

7.3. Potency test

Potency evaluation of the prepared polyvalent inactivated respiratory viral (pneumo-5) vaccines adjuvant with the both type Gel and Oil . and was carried out according to (Maha , 2012 )and (Rasha, et al.,2016).

8. Keeping quality of prepared vaccines: For measuring the efficacy evaluation of both 
type of pneumo-5 vaccine, samples of the same batch of the combined inactivated vaccines were kept at various temperatures for different intervals as follows:

8.1 Effect of temperature at $4-8^{\circ} \mathrm{C}$ : Both type of stored vaccine Pneumo-5 was tested every month post storage till 16 months for Gel type and monthly till 26 months for Oil type post storage.

8.2 effect of temperature at room temperature $\left(18-22^{\circ} \mathrm{C}\right)$ : Both type of stored Pneumo-5 vaccines was tested every week post storage till one month post storage.

8.3 Effect of temperature at incubator $\left(37^{\circ} \mathrm{C}\right)$ : Both type of stored Pneumo-5 vaccines was tested every week post storage till one month post storage.

Both type of stored Pneumo-5 vaccines was tested every week post storage till one month post storage.

9. Serum samples
Serum samples were collected from all calves on the first day of vaccination (0 day), the day of booster vaccination (14 days post vaccination) then every 2 week for Gel pneumo-5 Vaccine and every month for Oil pneumo-5 Vaccine to detect potency sample titre .Other keeping quality samples were collected at time of potency sample according to vaccine type. All serum samples were collected and inactivated at $56^{\circ} \mathrm{C}$ for 30 minutes in a water bath for inactivation of nonspecific substances, then stored at $-20^{\circ} \mathrm{C}$ until used in detection of specific neutralizing antibodies against all virus components of the prepared vaccine.

10. Serum neutralization test

It was performed on MDBK cell line using the micro titer technique. The sera samples were expressed as neutralization index was carried out according to Fulton et al. (1995), which protected $50 \%$ of the wells as calculated by Reed and Muench (1938).

\section{Results}

Table 1. Sterility test of the prepared both type Pneumo-5 vaccine .

\begin{tabular}{ccc}
\hline Vaccine & Examined microorganism & Result \\
\hline Gel & Aerobic bacteria & No colonies \\
& Anaerobic bacteria & No turbidity \\
& Fungus & No colonies \\
& Aerobic bacteria & No colonies \\
& Anaerobic bacteria & No turbidity \\
& Fungus & No colonies
\end{tabular}

Table 2. Safety test of the prepared both type of Pneumo-5 vaccine.

Animal observed

Sings

Mice

Calves

\begin{tabular}{ccccc} 
& Gel vaccine & Oil vaccine & Gel vaccine & Oil vaccine \\
\hline local reaction & Negative & negative & negative & Negative \\
systemic reaction & Negative & negative & negative & Negative
\end{tabular}


mortalities negative negative negative

Table 3:Mean serum neutralization indices in calves for gel adjuvanted prepared pneumo-5 vaccine viruses in weeks post vaccination(wpv):

\begin{tabular}{ccccc}
\hline virus & 0wp.v & 2wp.v & 4wp.v & 6wp \\
\hline BVD virus -1 & 0.0 & 0.2 & 1.2 & 1.5 \\
BVD virus -2 & $\ddots \cdot$ & 0.2 & 1.25 & 1.6 \\
IBR virus & $\ddots \cdot$ & 0.0 & 1.4 & 1.8 \\
PI-3 virus & $\ddots 1$ & 0.3 & 1.5 & 1.8 \\
BRS virus & 0.0 & 0.2 & 1.2 & 1.5 \\
control & 0.0 & 0.0 & 0.0 & 0.0 \\
\hline
\end{tabular}

Table 4: Mean serum neutralization indices in calves for oil adjuvanted prepared pneumo-5 vaccine viruses in month post vaccination(mpv):

\begin{tabular}{ccccc}
\hline Virus & 0mpv & $1 \mathrm{mpv}$ & $2 \mathrm{mpv}$ & $3 \mathrm{mpv}$ \\
\hline BVD virus -1 & $\ddots \cdot$ & 0.5 & 1.2 & 1.5 \\
BVD virus -2 & $\ddots \cdot$ & 0.55 & 1.25 & 1.6 \\
IBR virus & $\ddots \cdot$ & 0.6 & 1.4 & 1.8 \\
PI-3 virus & $\ddots \cdot$ & 0.8 & 1.5 & 1.8 \\
BRS virus & $\ddots \cdot$ & 0.7 & 1.2 & 1.5 \\
control & $\ddots \cdot$ & 0.0 & 0.0 & 0.0 \\
\hline
\end{tabular}

Table (5) : Heat stability along period storage of in months of storage of both type pneumo-5 vaccines at $4-8 \mathrm{C}^{0}$.

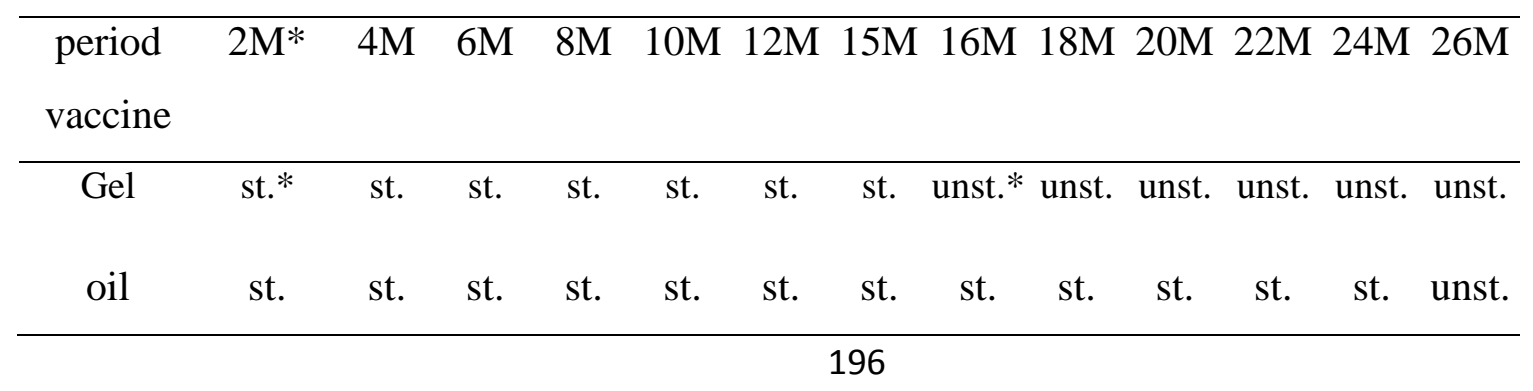


$\mathrm{M}$ :month post storage

st. :stable (had potency sample titre nearly resembled the potency of 0 day storage sample).

unst. :unstable(had potency sample titre $80 \%$ or less of the potency of 0 day storage sample).

'Table (6): Heat stability along period of storage in weeks of storage of both type pneumo-5

vaccines at different storage temperature.

\begin{tabular}{ccccc}
\hline $\begin{array}{c}\text { period } \\
\text { vaccine }\end{array}$ & 1 week & 2week & 3 week & 4 week \\
\hline Gel $\left(18-25 \mathrm{C}^{0}\right)$ & Stable & Stable & unstable & Unstable \\
Gel $\left(37 \mathrm{C}^{0}\right)$ & Stable & Unstable & unstable & Unstable \\
Oil $\left(18-25 \mathrm{C}^{0}\right)$ & Stable & Stable & stable & Unstable \\
Oil $\left(\left(37 \mathrm{C}^{0}\right)\right.$ & stable & Stable & unstable & Unstable \\
\hline
\end{tabular}

week :weeks post storage

st. :stable (had potency sample titre nearly resembled the potency of 0 day storage sample).

unst. : unstable(had potency sample titre $80 \%$ or less of the potency of 0 day storage sample).

\section{Discussion}

Respiratory disease occurs due to stress factors as bad environment, transportation, accumulation of ammonia and excessively high humidity in closed areas which lower the resistance of animal and enhance the multiplication of microorganisms (Bickert and Herdt, 1985). Infectious agents associated with bovine respiratory diseases include five viruses; BVD-1, BVD-2, IBR, PI-3 and BRS (Samira et al., 2001). Vaccination programs for breeding herds are integral parts of preventive health programs designed to lessen the effects of infectious respiratory diseases in cattle (Knezevic et al., 1990).

Currently the prepared vaccine showed complete absence of any bacterial, fungal or mycoplasma contamination on specific media for 15 days post inoculation. Moreover, the results of sterility test revealed that the prepared vaccines were also free from any infectious (Table 1). The obtained results supported safety tests when applied on mice and calves vaccinated with double times of vaccinal dose, where there was neither local nor systemic post vaccinal reaction and, there was no development of any clinical signs or elevation of rectal temperature during the whole experiment period (Table 2). Such findings agreed with those obtained by Parker et al. (2009). Judgement of stability on this study by two methods, firstly physically ( no change in colour or vaccine homogencity ), secondly immunologically by Serum neutralization test which has been used for quantization of antibodies against vaccinal viruses. The test is sensitive, mostly specific and relatively simple to be performed according to Rossi and Kiessel (1971). The antibody titres were expressed as the $\log _{10}$ of the inverse dilution which protected $50 \%$ of the tubes as calculated by Reed and Muench (1938). (Table 3,4)The results of the antibody titre expressed by neutralization index was indicated that vaccine was potent at 6 week post first inoculation dose incase of gel adjuvanted Pneumo-5 vaccine but three month post first inoculation in case of oily adjuvanted Pneumo-5 vaccine by using SNT that agree with ) (Maha , 2012)., (rasha et al., 2016). this result act as guide and model for judgment on immunological stability of other samples (the result of sample must around the result of model not less than $95 \%$ of the guide 
result ,the unstable sample show $80 \%$ of the guide result ).

The potency evaluation of the thermo stability of prepared polyvalent viral vaccine in calves Pneumo-5 vaccine. That by inoculate every animal with first dose at 0 day then boostering after 2 weeks from each sample. (Tables 5,6) showed that the Gel adjuvanted Pneumo-5 vaccine gave 100\% protection (the same poteny result of freshly prepared vaccine) for storage the vaccine at (4 $\left.-8^{\circ} \mathrm{C}\right)$ for 15 months; at $\left(18-25^{\circ} \mathrm{C}\right)$ for 2 week and at $\left(37^{\circ} \mathrm{C}\right)$ for 1 week, While Gel adjuvanted Pneumo-5 vaccine gave 100\% protection (the same poteny result of freshly prepared vaccine) storage of the vaccine at (4$\left.8^{\circ} \mathrm{C}\right)$ after 24 months; at $\left(18-25^{\circ} \mathrm{C}\right)$ after 3 weeks and at $\left(37^{\circ} \mathrm{C}\right)$ for 2 weeks. So it could be concluded that $4-8^{\circ} \mathrm{C}$ is the best temperature for storage of the inactivated pneumo-5 vaccine gel or oil adjuvanted this agree with Mohamed Mostafa (1984) and Ehab El-Sayed et al ,(2012).

\section{Conclusion:}

The thermo stability of combined respiratory inactivated vaccine (Pneumo5) with its both type which kept in refrigerator at $4-8^{\circ} \mathrm{C}$ is valid to use for 15 months of storage for gel type and 24 month for oil adjuvanted type .And this is the suitable storage temperature for both type of Pneumo5 vaccine These results are very useful for the farmers, veterinarians and their assistances who used this vaccine under different environmental conditions.

\section{REFERENCES}

Abdel-Fadil, Maha R. (2007): Serosurveillance of Bovine Viral Diarrhea Genotype in Breeding Farm Animal in Egypt. Master degree, Benha University ,Faculty of Veterinary Medicine, Virology Department .

Abdel-Fadil, Maha R. (2012): Studies on pneumogen-5 vaccine which containing viruses causing diarrhea and respiratory symptoms in cattle . PH.D , Benha University ,Faculty of Veterinary Medicine, Virology Department

Bahnemann HG (1975). Binary ethyleneimine as an inactivant for FMD and its application for vaccine production. Arch. Virol., (47): 46-56.

Barteling SJ, Van Maanen C, Yadin H, Anemaet DAJ (1990). A FMD vaccine bank. Purified inactivated antigen stored at ultra-low European commission for the control of foot and mouth disease. Session of the research group of the standing technical committee, Lindholm: 172177.

Bickert, E.A. and Herdt, T.H. (1985): Environmental aspects of dairy calves housing comperdium on continuing education for the practicing veterinarians, 7: 5309.

Ehab El-Sayed*, Wael Mossad Gamal El-Din, Sonia Ahmed Rizk, Magdi Abd ElAty(2012):Effect of Different Storage Temperatures on the Efficacy of the Bivalent Foot and Mouth Disease Oil Vaccine. Journal of Advanced Veterinary Research Volume 2 (2012) 198-205.

FAO (1971): Vaccine Manual. The production and quality control of veterinary vaccines for use in developing countries. FAO Animal Production and Health Series, p. 291.

Fulton, R.W.; Confer, A.W.; Burge, L.J.; Porino, L.J.; D'Offay, J.M.; Payton, M.E. and Mock, R.E. (1995): Antibody viral vaccines containing BHV, BVD, PI-3 and BRSV immunogens and subsequent revaccination at day 140. Vaccines, 13: 725-733.

Fulton, R.W.; Cook, B.J.; Step, D.L.; Confer, A.W.; Saliki, J.T.; Payton, M.E.; Burge, L.J.; Welsh, R.D. and Blood, K.S. (2002): Evaluation of health status of calves and the impact on feedlot performance assessment of retained ownership programs for post weaning calves. Cand. J. Vet. Res., 66: 173-180.

Girard, H.C., Bayramoglu, O.I., ErLN and Burghut. (1977): Inactivation of viruses by binary Ethylenimine. Bull. IntIpid 87 (3-4):201-207.

Knezevic, N.; Kosanovic, P. and Rogan, D. (1990): Immuno prophylaxis of 
respiratory diseases of cattle with inactivated vaccine. III. Study of the immunogenicity of a bivalent inactivated oil

Lei, J.C. (1985):Aluminium hydroxide gel. Guideline for adsorption. Vaccine, 3 : 54-55.

Mohamed Mostafa (1984) :Effect of storage and temperature on the FMD vaccine in cattle under field environment. Faculty of Veterinary Medicine, Infectious Diseases, Cairo Univ.

Parker RS, Deville L, Dupius F, Aucouturier BJ (2009). Adjuvant formation for veterinary vaccines, Montanide gel, safety profile. Procedia Vaccinol., 140-147.

Rasha,I.EL-Hawary and Hanaa A. Mostafa (2016): Immunological response of locally prepared oil adjuvanted pneumo-5 vaccine in calves . journal of veterinary medical research 2017 , 24 (1).

Reed, L.T.,and Muench, H. A. (1938): Simple method of calculating fifty percent end point. Am $J$ Hyg 1938;27:493-8.

Ridpath, J. F. (2005):Practical significance of heterogeneity among BVDV strains: impact of biotype and genotype on
U.S. control programs. Prev. Vet. Med. 15; 72(1-2):17-30.

Rossi, C.R. and Kiessel, G.K. (1971): Microtitre for detecting antibody in bovine serum to PI-3 V, IBRV and BVDV. Microbiol., 22: 32-36.

Samira, S.T.; El-Sabbagh, M.M.A. and Ghaly, H.M. (2001):Preparation of combined inactivated BVD, IBR, PI3 and respiratory syncytial virus (BRSV).J. Egypt. Vet. Med. Ass. 61, no. 4: 251-263.

Seppic, Paris, France (2002). Montanide ISA adjuvant for large animal vaccine. Seppic limited Incorporation company.

Singh, K.V. and Thanaa, I. Baz (1966): Isolation of PI-3 $\mathrm{V}$ from water buffaloes in Egypt. Can. J. Comp. Med. And Vet. Sci., 31: 70-79.

Voller, A., Bidwell, D.E. and Annbarlett, M. (1976):Enzyme immuno assays in diagnostic medicine, theory and practice. Bull.World. Health, organ, 63: 55-65.

Zeidan SM, Eman KAK , and Baker AM (1999). Preliminary studies for production and evaluation of inactivated respiratory syncytial virus vaccine (BRSV). Egypt J. Agric. Res. 